\title{
MPPT STRATEGY FOR A PMSG BASED RAPS NETWORK USING MATLAB
}

\section{ROHIT SINHA $^{\mathbf{1}} \&$ VIRENDRA KUMAR MAURYA ${ }^{\mathbf{2}}$}

${ }^{l}$ Scholar M. Tech (PS\&C,) Babu Banarasi Das University, Lucknow, Uttar Pradesh, India

${ }^{2}$ Associate Professor, Babu Banarasi Das University, Lucknow, Uttar Pradesh, India

\begin{abstract}
The RAPS network in rural areas has been used to supply power where the utility grid is not present or not easily available. The RER have gained popularity now-a-days against conventional generators. In order to maintain the proper functioning of the RAPS network, we need to go for Maximum Power Point Tracking (MPPT) strategy. This work suggests to carry out MPPT strategy for a PMSG based RAPS network using boost converters. In MPPT, we will have to find the instances during which the network delivers the maximum power to the entire network. Boost Converters are usually DC-DC converters. It is used to step-up the voltage to a voltage which is greater than the source voltage. Here, the output voltage is always higher than the input voltage. Here, we find out the instances at which the network delivers maximum power. It will help to increase the efficiency of the network.

KEYWORDS: PMSG-Permanent Magnet Synchronous Generator, RAPS- Remote Area Power Supply, MPPTMaximum Power Point Tracking, UCs- Ultra-Capacitors, WECS- Wind Energy Conversion Systems, RER-Renewable Energy Resources, HESS-Hybrid Energy Storage Systems
\end{abstract}

Received: Apr 10, 2020; Accepted: Apr 30, 2020; Published: May 18, 2020; Paper Id.: IJAuERDJUN20204

\section{INTRODUCTION}

The renewable energy (e.g., wind, solar) is a need of the hour in order to reduce the despendent nature of fossil fuels. The main problem with renewable power generation is that it cannot be used as per demand and as per requirements. The use of RER has played a vital role on the operations of RAPS systems. Therefore, it becomes very difficult to maintain the stability and reliability of RAPS network. Now-a-days, it has become very difficult for conventional generators to meet the requirements of the RAPS systems for their proper functioning. RAPS system is an independent type of network that supplies power to small rural areas. In rural areas, the grid is not available and it is impossible to extend the grid to these areas.

In order to maintain the proper functioning of the RAPS network, we need to go for Maximum Power Point Tracking (MPPT) strategy. In MPPT, we will have to find the instances during which the network delivers the maximum power to the entire network. In a PMSG based RAPS network, the wind turbine delivers the maximum power at $12 \mathrm{~m} / \mathrm{sec}$ wind speed. The wind turbine block in MATLAB is a function of wind speeds and pitch angle (beta). It mainly depends on the nature and speed of the wind. Figure-1 shows the wind turbine power characteristics of the wind turbine in MATLAB at pitch angle beta $=0$ deg. From this figure, the wind turbine delivers maximum power or maximum turbine power output at $12 \mathrm{~m} / \mathrm{sec}$ wind speed and at 1.2 p.u. turbine speed. The wind turbine delivers maximum power at $12 \mathrm{~m} / \mathrm{sec}$ wind speed. 


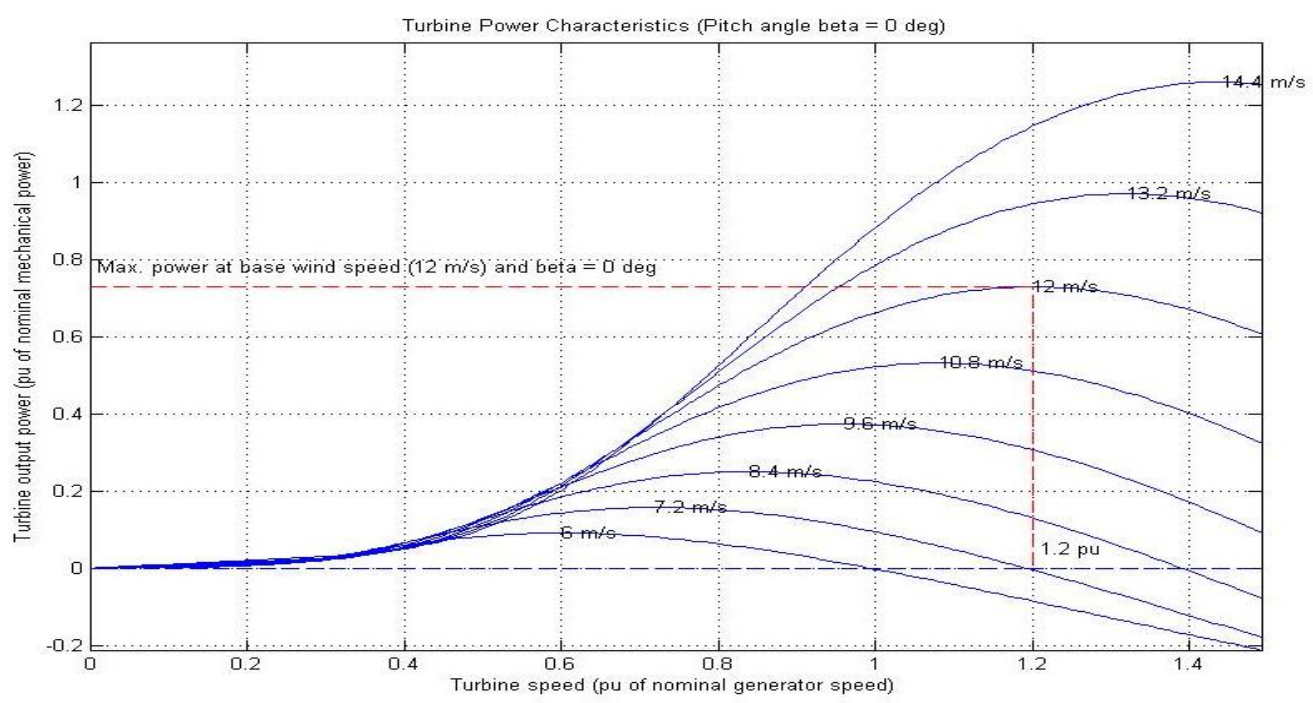

Figure 1: Wind Turbine Power Characteristics at Pitch Angle Beta=0 Degrees.

To carry out MPPT, we will be utilising boost converters in the mid of the dc link of the RAPS network. The boost converters consists of an inductor, a semi-conductor switch or switching device, a diode and a capacitor connected across the load. Here, we have used IGBT as the switching device in the boost converter. Boost Converters are usually DCDC converters. They are also known as step-up converters. It is used to step-up the voltage to a voltage which is greater than the source voltage. It is used for DC to DC conversion purposes. Here, the output voltage is always higher than the input voltage. Here, we find out the instances at which the network delivers maximum power in order to carry out MPPT strategy.

\section{WORKING PRINCIPLE}

The research work is carried out with the help of tools like MATLAB software. with a version, MATLAB R2013a 64 bit software. The elements like wind turbine block, PMSG (Permanent Magnet Synchronous Generator), rectifier block, diode, IGBT, pulse generator, inverter block, inductor, capacitor, 3-phase VI measurement block, LC filter block, ultra-capacitor block, battery block, 3-phase transformer, 3-phase RLC load block, etc. required in our work will be taken from "Sim power systems" tool box under "Sim scape" icon present in Simulink library of the MATLAB. The elements like From and Goto required in our work is taken from "Signal Routing" tool under "Simulink" icon that is present in Simulink library of the MATLAB. "Battery" and "Ultra-capacitors" block is utilized for hybrid energy storage systems for maintaining the power supply in the network or RAPS systems and improving the stability and reliability of the network. "Powergui" block is used as a generator to the model in order to make it run in MATLAB. "Scope" and "Workspace" block is also utilized under "Sink" icon present in Simulink library of the MATLAB in order to record the observations or responses after simulating the model. The model is made to run at $50 \mathrm{~Hz}$ frequency. First of all, all the blocks are initialized as per requirements and then the model is made to run to check if there are errors present in it or not. Then, the Simulink model is made to run or simulate by using MATLAB R2013a 64 bit software tool. The responses are observed by the help of scope or workspace.

The HESS (UCs and Lithium-ion battery), is interfaced into a PMSG based WECS. First of all, the wind turbine rotates to generate the mechanical torque. Then, the torque is given as input to the PMSG. PMSG is used to convert the mechanical work done by the wind turbine to electrical energy. The output voltage of PMSG is given as an input to the 
diode bridge rectifier. The diode bridge rectifier converts the input sinusoidal alternating voltage to the DC voltage and passes on to the associated network. The DC voltage is converted to alternating voltage by means of an IGBT/ diode based inverter. The energy storage devices, i.e., UCs and lithium-ion batteries are connected to the DC side, which is in between the rectifier and inverter end. It acts as a branch in between the rectifier and inverter end. In between the rectifier and the inverter end, the boost converter is inserted in the mid of the dc link. The boost converter comprises of an inductor, IGBT switching device, a diode and a capacitor connected across the dc link. The boost converter is used here to carry out the Maximum Power Point Tracking (MPPT) strategy in order to deliver the maximum power to the entire network. The output power generation through IGBT/ diode bridge inverter is then made to pass through a three phase transformer by connecting a LC-filter in between them. The output is then provided further to the RAPS network system. The "From" and "Goto" are used to find out the power at the rectifier end, inverter end and at the load end.

\section{COMPONENTS}

The components present in this work are as follows:-

- Wind turbine.

- Permanent Magnet Synchronous Generator (PMSG).

- Ultra-Capacitors.

- Batteries.

- Boost Converters

Wind Turbine: A wind turbine also known as wind energy converter is used to convert the wind's kinetic energy to electrical energy. A wind turbine consists of a turbine which is rotated by means of wind. The wind acts as an input to the wind turbine. The wind turbine is used to generate the mechanical torque, which is then taken as an input to get the electrical energy. The wind turbine has 2 different types of axis-vertical axis and horizontal axis. The smallest of all the wind turbines are used for providing power to traffic warning signs and charging of battery of boats. The turbines can rotate in horizontal axis manner or vertical axis manner. The horizontal axis is the older one and the most common one. The wind turbines mostly have a gearbox. The windturbines are mostly used for production of electric power commercially.

Permanent Magnet Synchronous Generator (PMSG): PMSG stands for permanent magnet synchronous generator. It is a type of generator where the permanent magnet provides the excitation field. The term synchronous refers to the fact that the rotor and stator rotate with the same speed, andpermanent magnet generates the magnetic field and current gets induced into the armature.

In PMSG, the "rotor" is the permanent magnet, and the "stator" is the armature, which is connected to the load end. Both the stator and the rotor maintain their synchronism with respect to their rotation. The rotor i.e. permanent magnet of the PMSG rotates due to the input given as mechanical torque by the wind turbine. The movement of permanent magnet leads to generate flux which in turn leads to generate the emf and finally leads to generate the voltage at the armature windings. The output voltages of PMSG consists of three phase voltages, which are phase shifted to each other by an angle of 120 degrees. The stator winding of the PMSG carries the three phase armature windings and are electrically displaced by 120 degrees from each other producing an ac voltage output. 
Ultra-Capacitors: An ultra-capacitor is known as super-capacitor. It is an electrical component capable of holding electrical charge hundreds of times than a standard capacitor. It is useful in devices which require low current and low voltage. They are normally used in emergency radios and flashlights.

The UC requires charging before its mode of operation. Once the UC is fully charged, it can function for some period of time till it gets fully discharged or it requires charging. Once it is fully charged, then current stops flowing and the UCs output voltage is equal to the voltage of the supply. A fully charged UC will store energy till it gets fully discharged. When the UC is in discharging mode, then the stored energy gets converted into electrical energy to supply to the load present within the network. UCs are always connected in parallel manner with the network. UCs comprises of a very high value of capacitor and very less value of resistor connected in series manner. A high value of capacitor and less value of resistor are connected in series manner and the whole arrangement is connected in parallel with the circuit or the network. It always contains very high value of capacitance.

Batteries: A battery consists of one or more electro-chemical cells, which are connected to provide power to the devices like flashlights, smartphones, etc., In MATLAB, the battery (mask) is present, in which different types of batteries are found, which are connected in series with the circuit. There are many different types of batteries in MATLAB. Any one type of battery can be chosen at a time. Here, we have used lithium-ion battery.

Boost Converters: Boost Converters are usually DC-DC converters. They are also known as step-up converters. It is used to step-up the voltage to a voltage which is greater than the source voltage. It is used for DC to DC conversion purposes. Here, the output voltage is always higher than the input voltage.

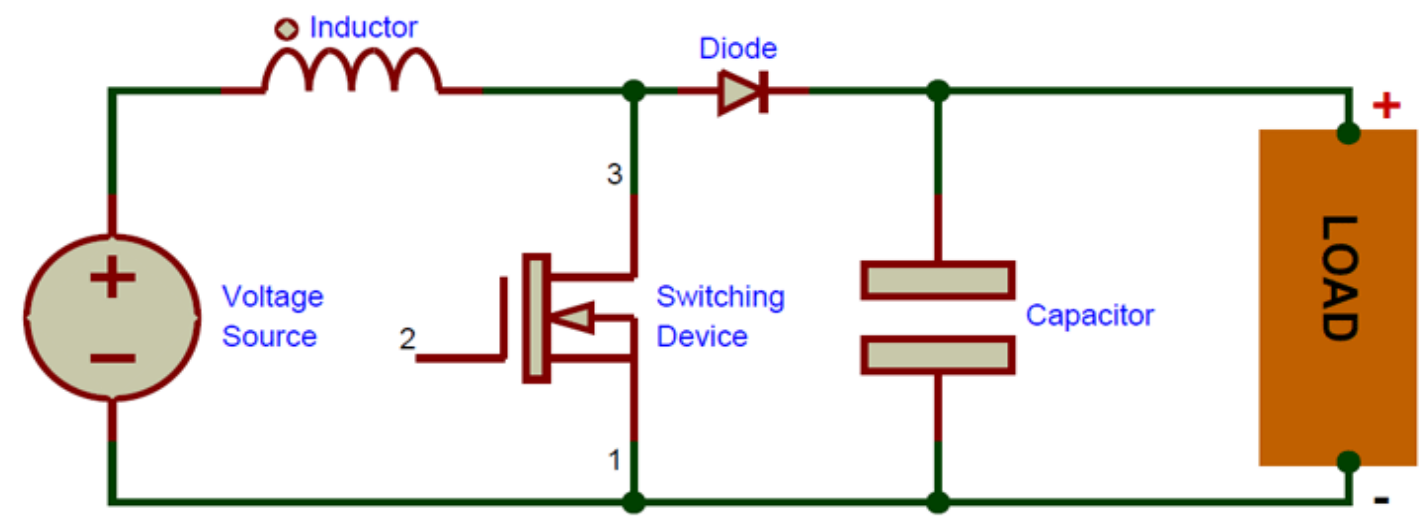

Figure 2: Circuit Diagram of Boost Converter.

It consists of an inductor, a semi-conductor switch or switching device, a diode and a capacitor connected across the load. Figure- 2 shows the circuit diagram of boost converter. The switching device may be an IGBT, MOSFET or BJT. Here, we have taken the switching device as IGBT. The boost converters have high efficiency. Here, when the switch or switching device is closed, the current flows through the inductor branch and the inductor stores some energy by generating a magnetic field. When the switch is open, current gets reduced and the magnetic field previously created gets destroyed to maintain current towards the load. At this point, a higher voltage comes into account to charge the capacitor through the diode. Hence, a higher voltage comes into action which is greater than the source voltage. 
PARAMETERS OF PMSG

Table 1: Parameters of PMSG

\begin{tabular}{|c|c|c|}
\hline $\begin{array}{l}\text { Sl. } \\
\text { No. }\end{array}$ & Parameters & Values \\
\hline 1. & Number of phases & 3 \\
\hline 2. & Back EMF waveform & Sinusoidal \\
\hline 3. & Rotor type & Round \\
\hline 4. & Mechanical input & Torque Tm \\
\hline 5. & Preset model & No \\
\hline 6. & Stator phase resistance Rs (ohm) & 0.425 \\
\hline 7. & Armature inductance $(\mathrm{H})$ & $8.35 \mathrm{e}-3$ \\
\hline 8. & Flux linkage established by magnets (V.s) & 1.225 \\
\hline 9. & $\begin{array}{l}\text { Inertia, viscous damping, pole pairs, static } \\
\text { friction }\left[\mathrm{J}\left(\mathrm{kg} \cdot \mathrm{m}^{\wedge} 2\right) \mathrm{F}(\mathrm{N} \cdot \mathrm{m} . \mathrm{s}) \mathrm{p}() \mathrm{Tf}(\mathrm{N} . \mathrm{m})\right]\end{array}$ & {$[2.26 \mathrm{e}-5 \quad 1.35 \mathrm{e}-5 \quad 100]$} \\
\hline 10. & $\begin{array}{l}\text { Initial conditions }[\mathrm{wm}(\mathrm{rad} / \mathrm{s}) \text { thetam( } \mathrm{deg}) \\
\mathrm{ia}, \mathrm{ib}(\mathrm{A})]\end{array}$ & {$[0,0,12,12]$} \\
\hline 11. & Sample time & -1 \\
\hline 12. & Rotor flux position when theta $=0$ & $\begin{array}{l}90 \text { degrees behind phase } \mathrm{A} \\
\text { axis (modified park) }\end{array}$ \\
\hline
\end{tabular}

\section{PARAMETERS OF DIODE}

Table 2: Parameters of Diode

\begin{tabular}{|c|l|c|}
\hline Sl. No. & \multicolumn{1}{|c|}{ Parameter } & Value \\
\hline 1. & Resistance Ron $(\mathrm{Ohms})$ & 0.001 \\
\hline 2. & Inductance Lon $(\mathrm{H})$ & 0 \\
\hline 3. & Forward voltage Vf $(\mathrm{V})$ & 0.8 \\
\hline 4. & Initial current Ic $(\mathrm{A})$ & 0 \\
\hline 5. & Snubber resistance Rs $(\mathrm{Ohms})$ & 500 \\
\hline 6. & Snubber capacitance Cs $(\mathrm{F})$ & $250 \mathrm{e}-9$ \\
\hline
\end{tabular}

\section{PARAMETERS OF IGBT}

Table 3: Parameters of IGBT

\begin{tabular}{|c|l|c|}
\hline Sl. No. & \multicolumn{1}{|c|}{ Parameter } & Value \\
\hline 1. & Internal resistance Ron (Ohms) & $1 \mathrm{e}-3$ \\
\hline 2. & Snubber resistance Rs (Ohms) & $1 \mathrm{e} 5$ \\
\hline 3. & Snubber capacitance Cs (F) & $5 \mathrm{e}-6$ \\
\hline
\end{tabular}

\section{SIMULINK MODEL}

The Simulink model is made in MATLAB R2013a 64 bit software and is checked for errors, if present. The Simulink model is made to run or simulate in MATLAB. 


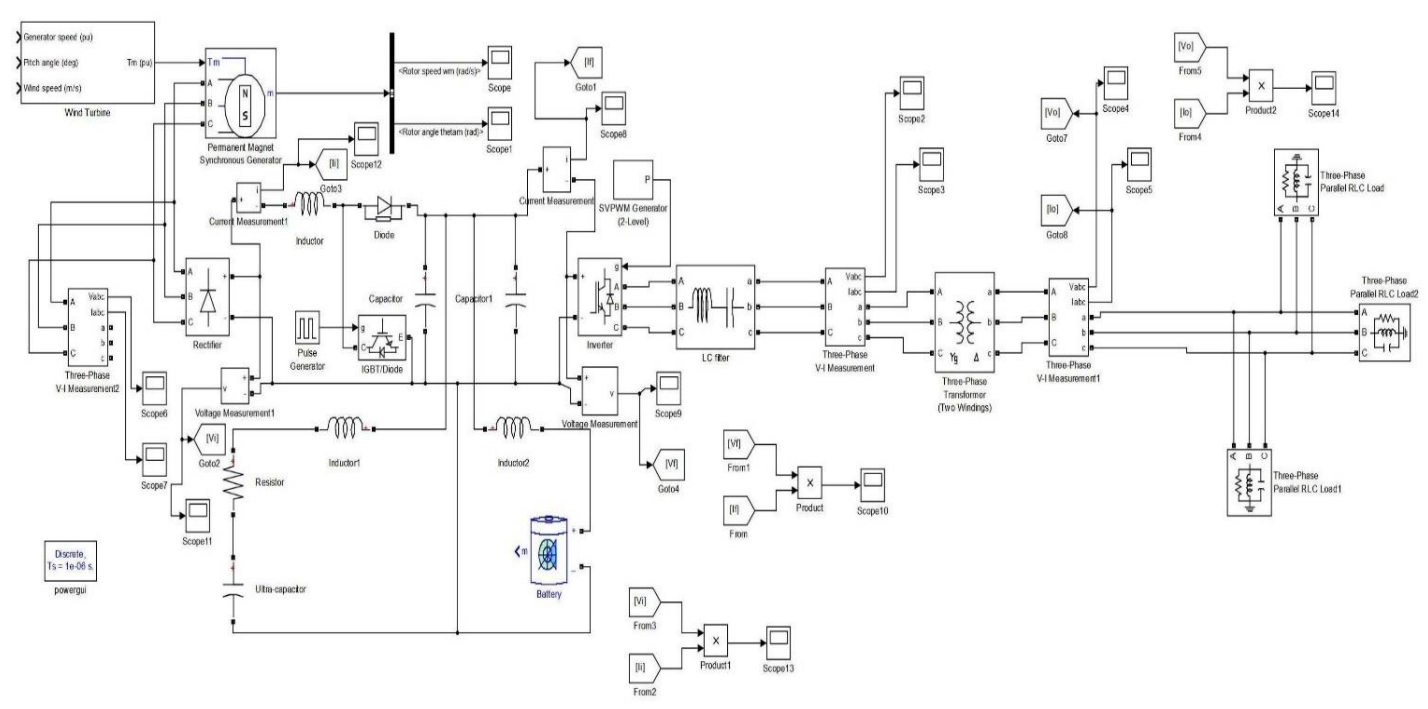

Figure 3: Simulink Model.

\section{RESULTS}

The Simulation or MATLAB model is made to run in MATLAB and the responses are recorded and observed.

1. Output Voltage of PMSG:-Voltage $=25383$ Volts $=25.383 \mathrm{KV}$.

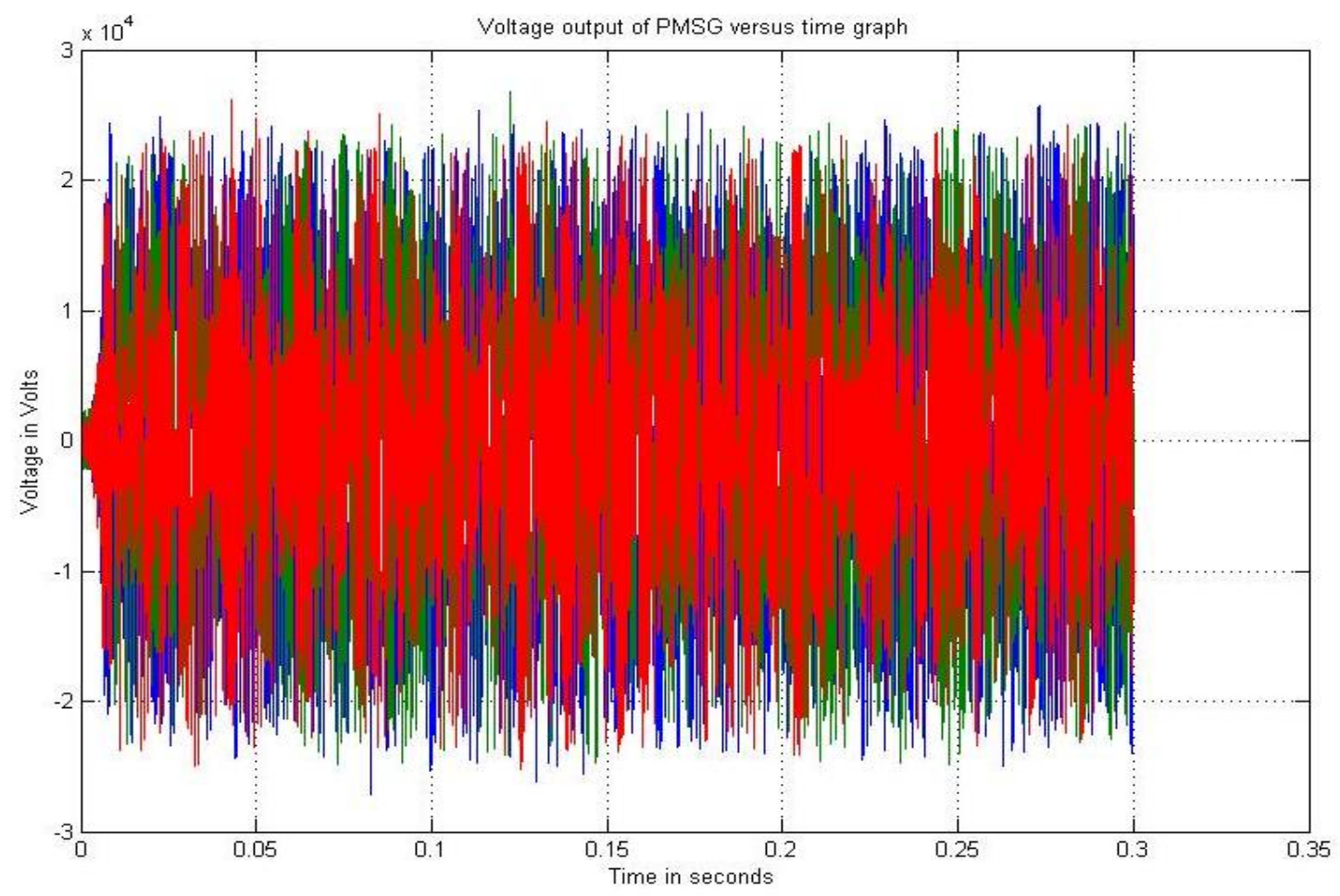

Figure 4: Output Voltage of PMSG.

The phase voltage output of the PMSG is found to be $=25383$ Volts $=25.383 \mathrm{KV}$. 
2. Voltage at the rectifier end:- Voltage $=6658$ Volts

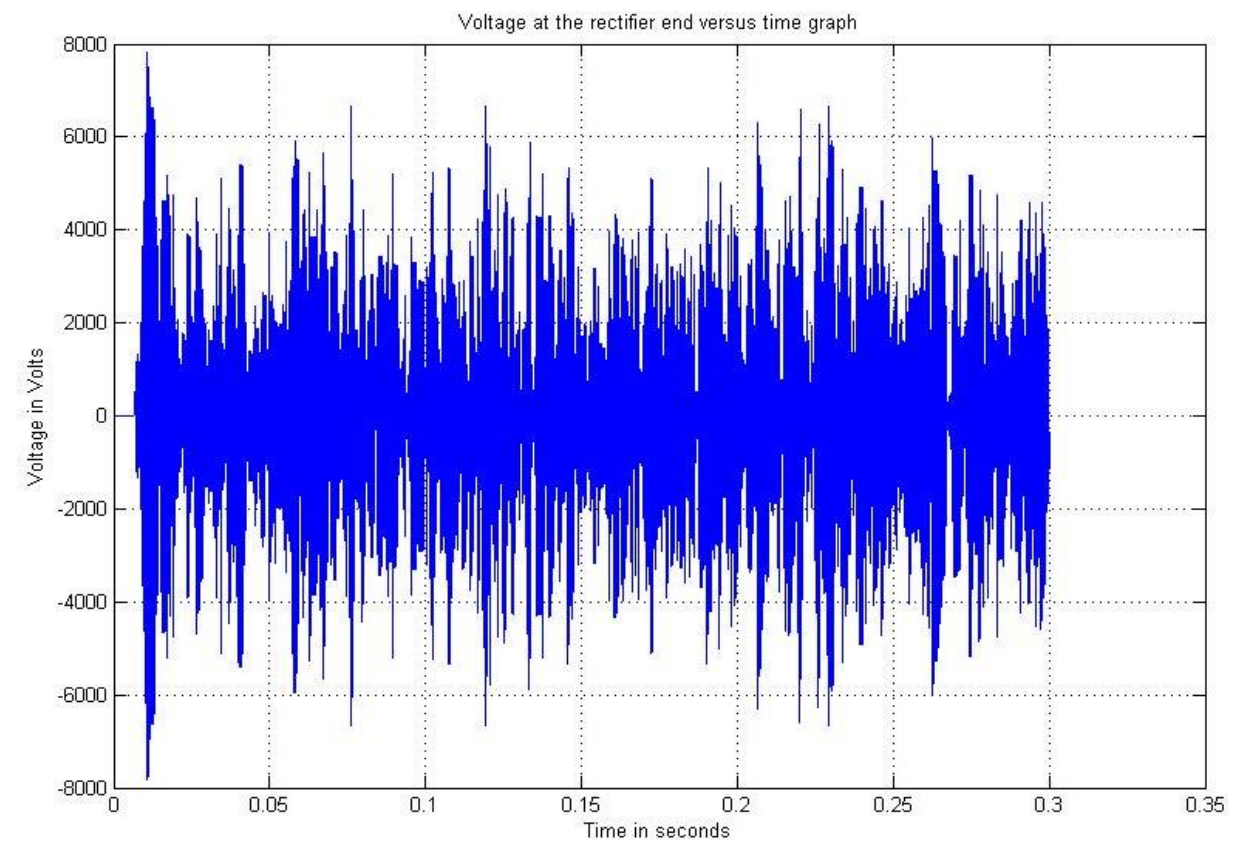

Figure 5: Voltage at the Rectifier End.

The voltage at the rectifier end is found to be $=6658$ Volts.

3. Current at the rectifier end:- Current $=279 \mathrm{~A}$

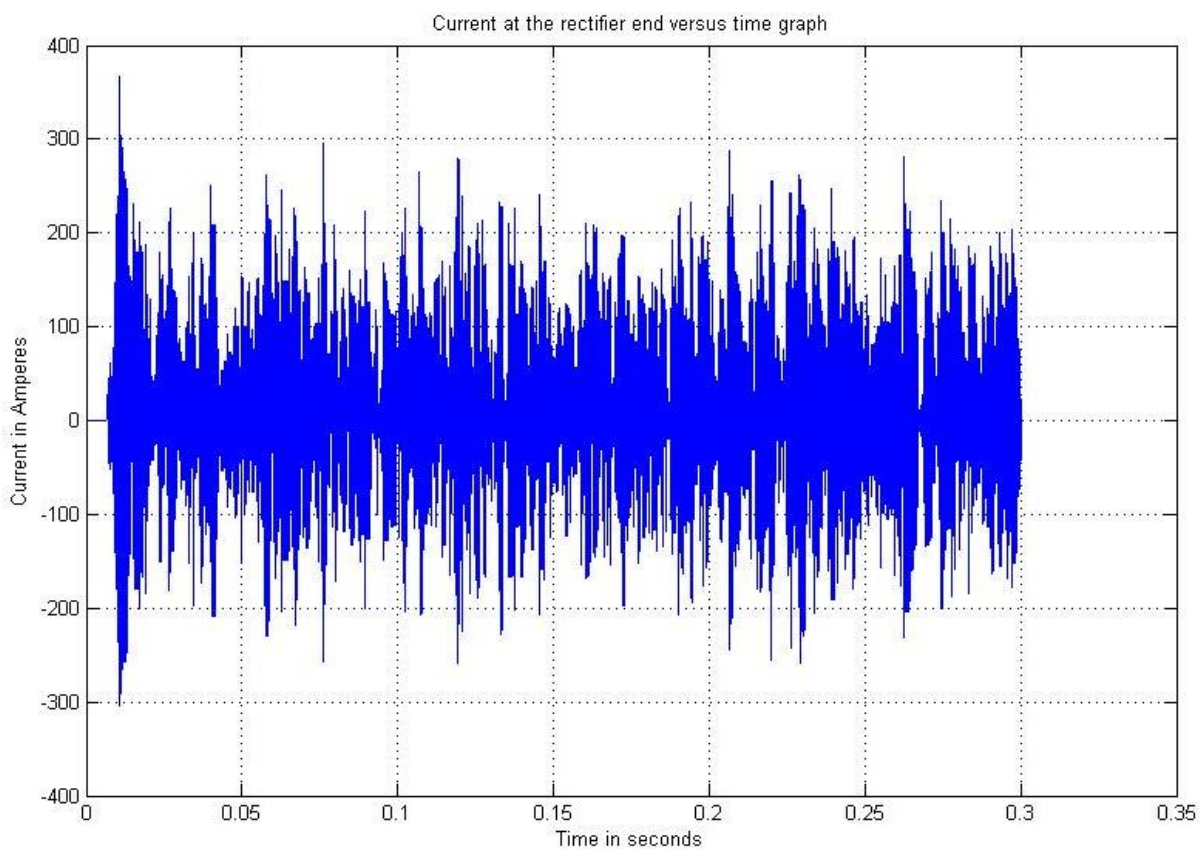

Figure 6: Current at the Rectifier End.

The Current at the rectifier end is found to be $=279 \mathrm{~A}$. 
4. Power at the rectifier end:-Power is maximum at $=1.235 \times 10^{6}$ Watts at 0.0106 sec.

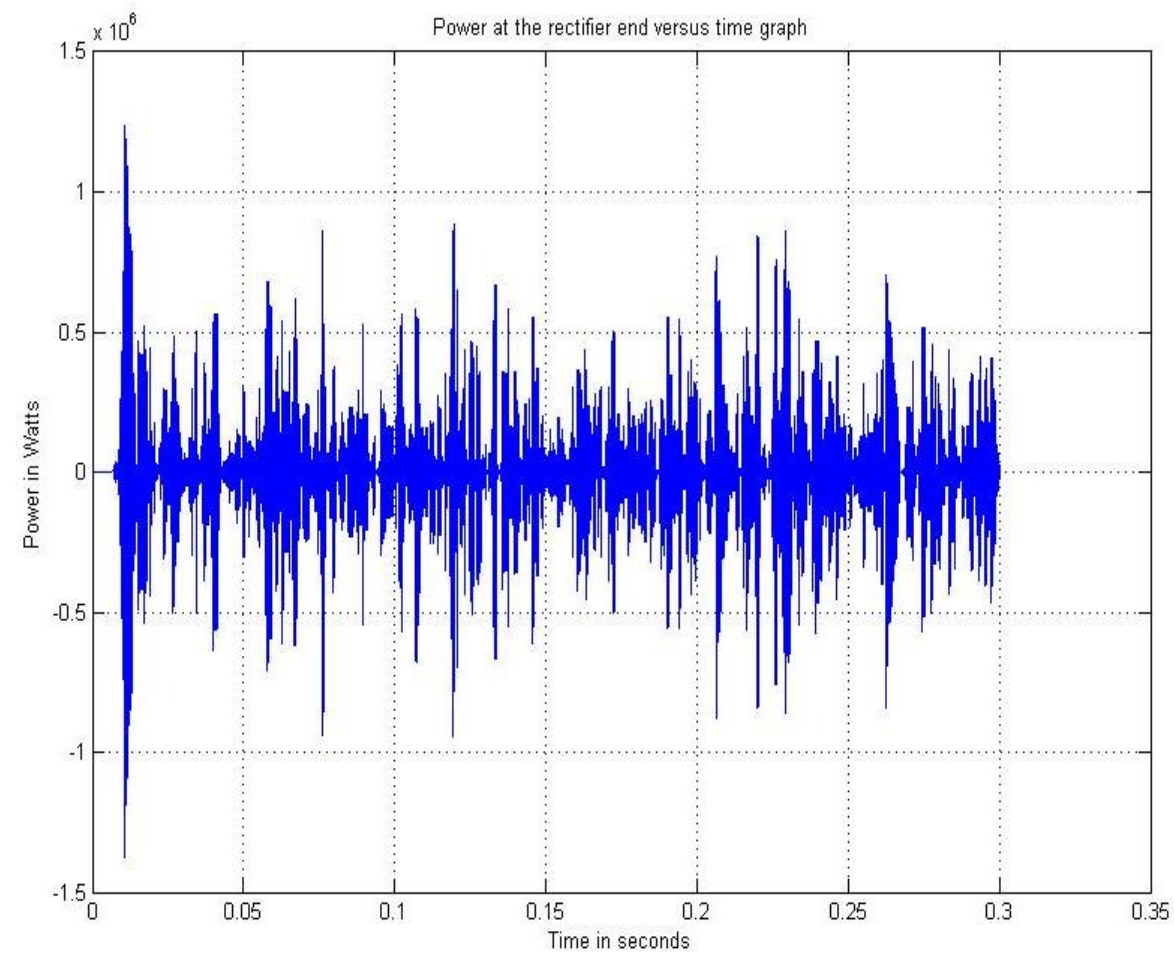

Figure 7: Power at the Rectifier End.

Here, power is found to be maximum at $=1.235 \times 10^{6}$ Watts at $0.0106 \mathrm{sec}$.

5. Current at the inverter end:- Current $=1440 \mathrm{~A}$

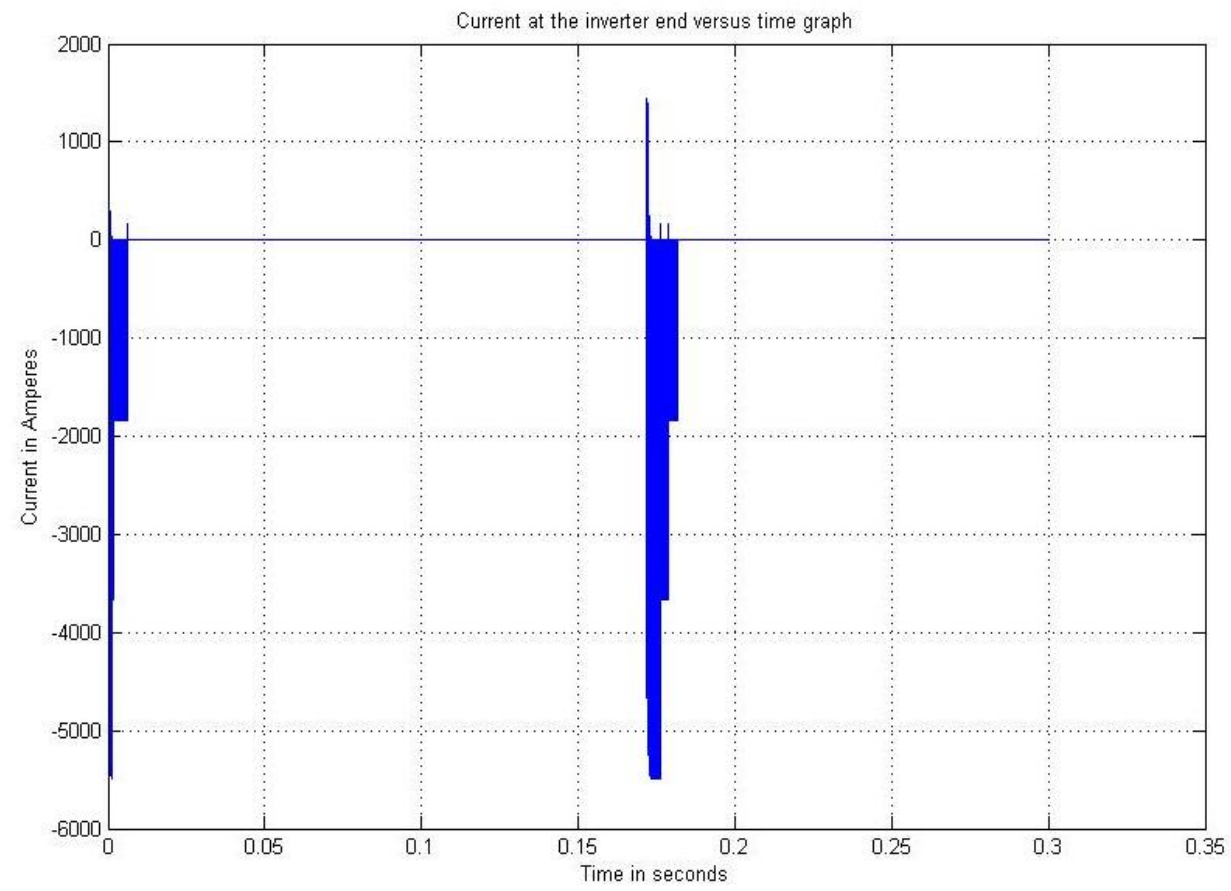

Figure 8: Current at the Inverter End.

The current at the inverter end is found to be $=1440 \mathrm{~A}$. 
6. Voltage at the inverter end:- Voltage $=5507$ Volts

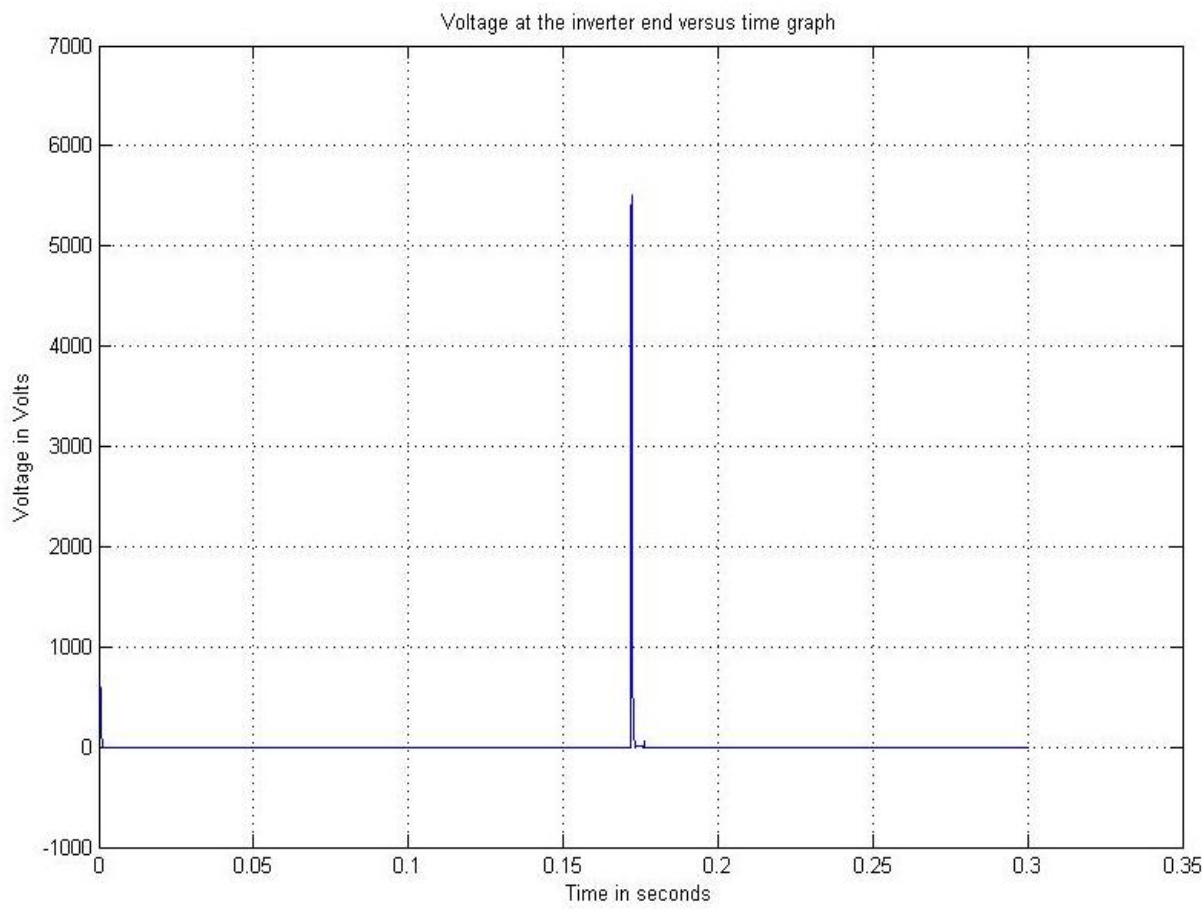

Figure 9: Voltage at the Inverter End.

The Voltage at the inverter end is found to be $=5507$ Volts

7. Power at the inverter end:- Power is maximum at $=7.48 \times 10^{6}$ Watts at $0.172 \mathrm{sec}$

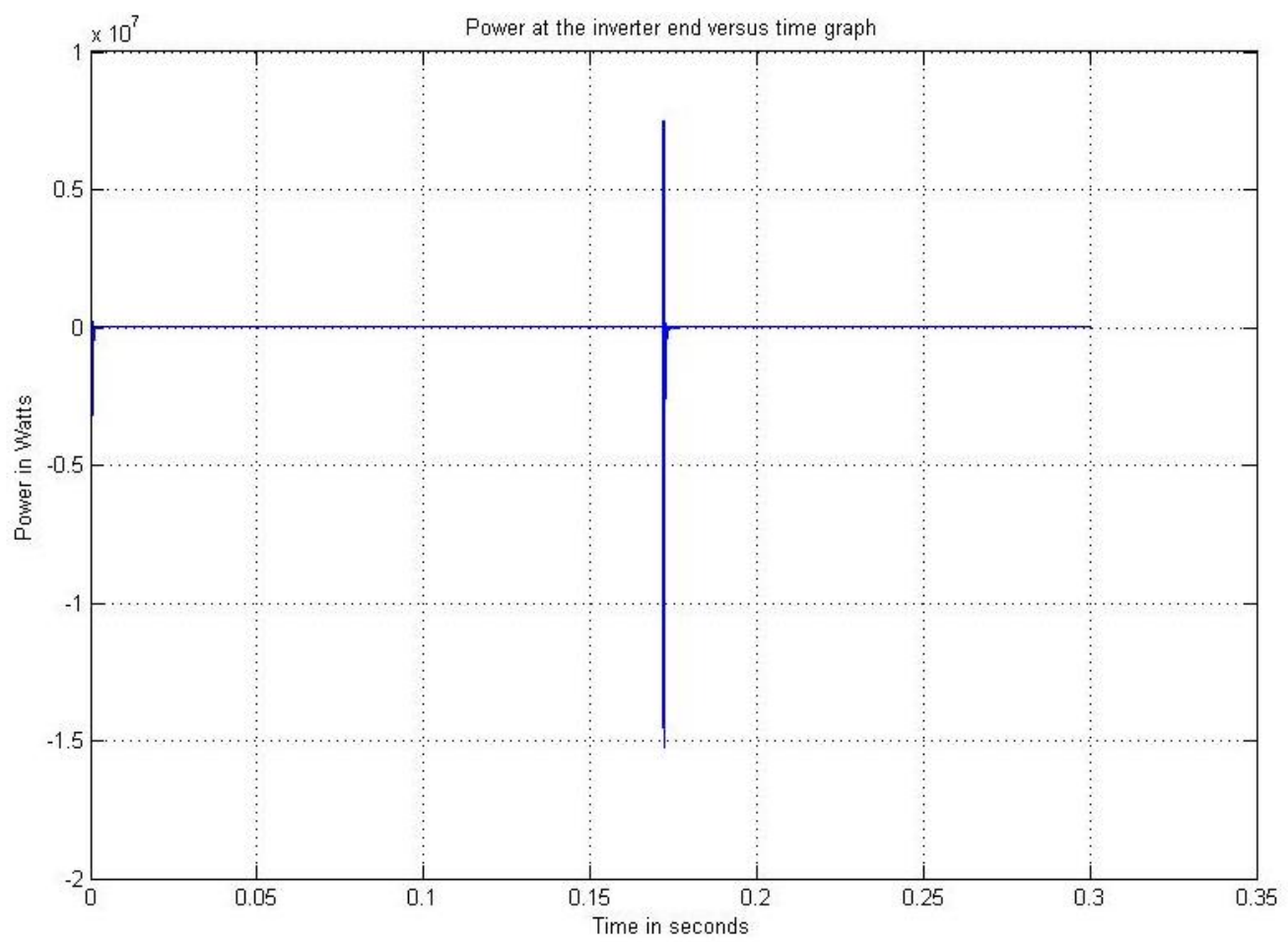

Figure 10: Power at the Inverter End.

Here, power is found to be maximum at $=7.48 \times 10^{6}$ Watts at $0.172 \mathrm{sec}$. 
8. Voltage Output at the Inverter End:- Voltage $=8802$ Volts

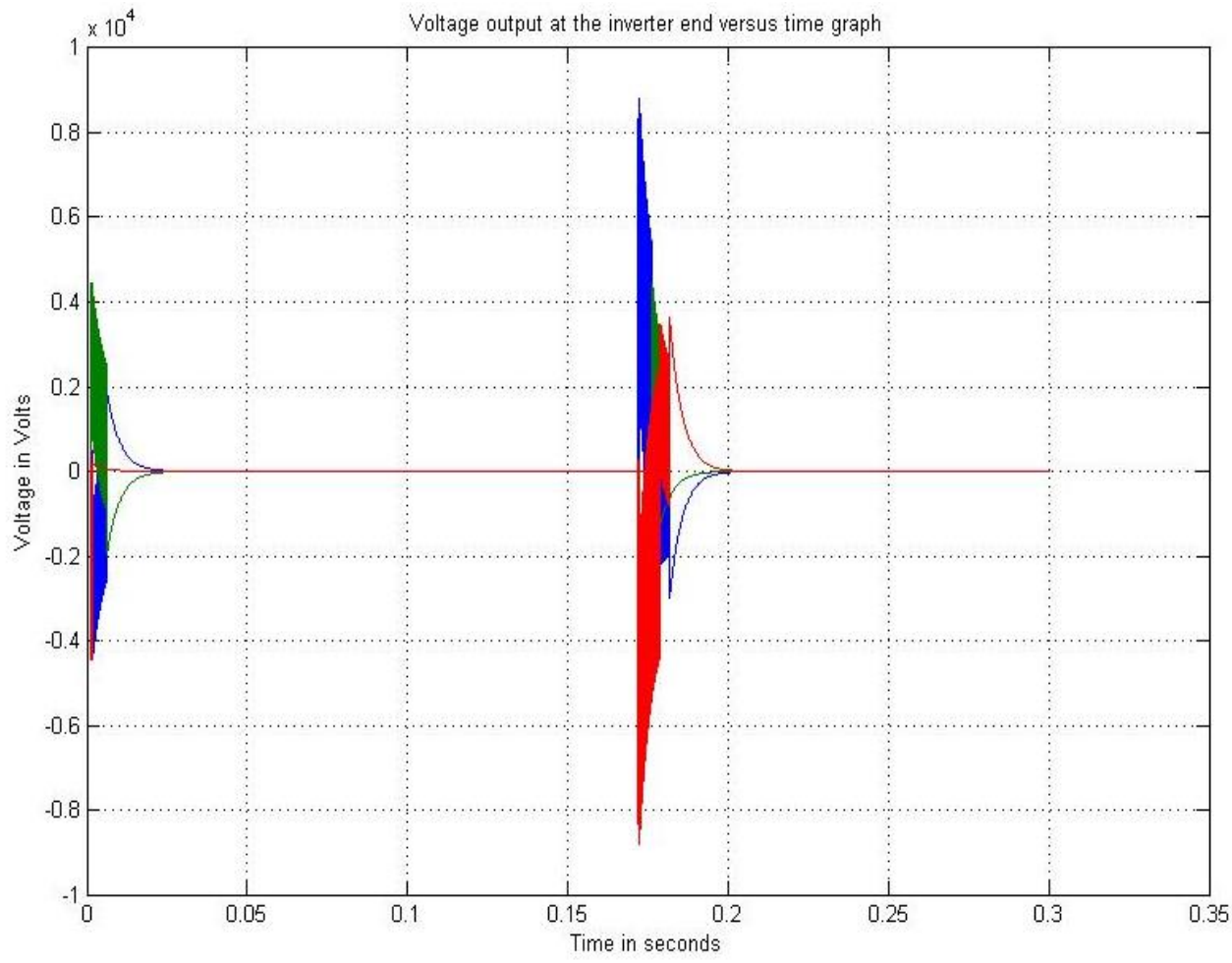

Figure 11: Voltage Output at the Inverter End.

The Voltage output at the inverter end is found to be $=8802$ Volts.

9. Current output at the inverter end:- Current $=0.84 \mathrm{~A}$

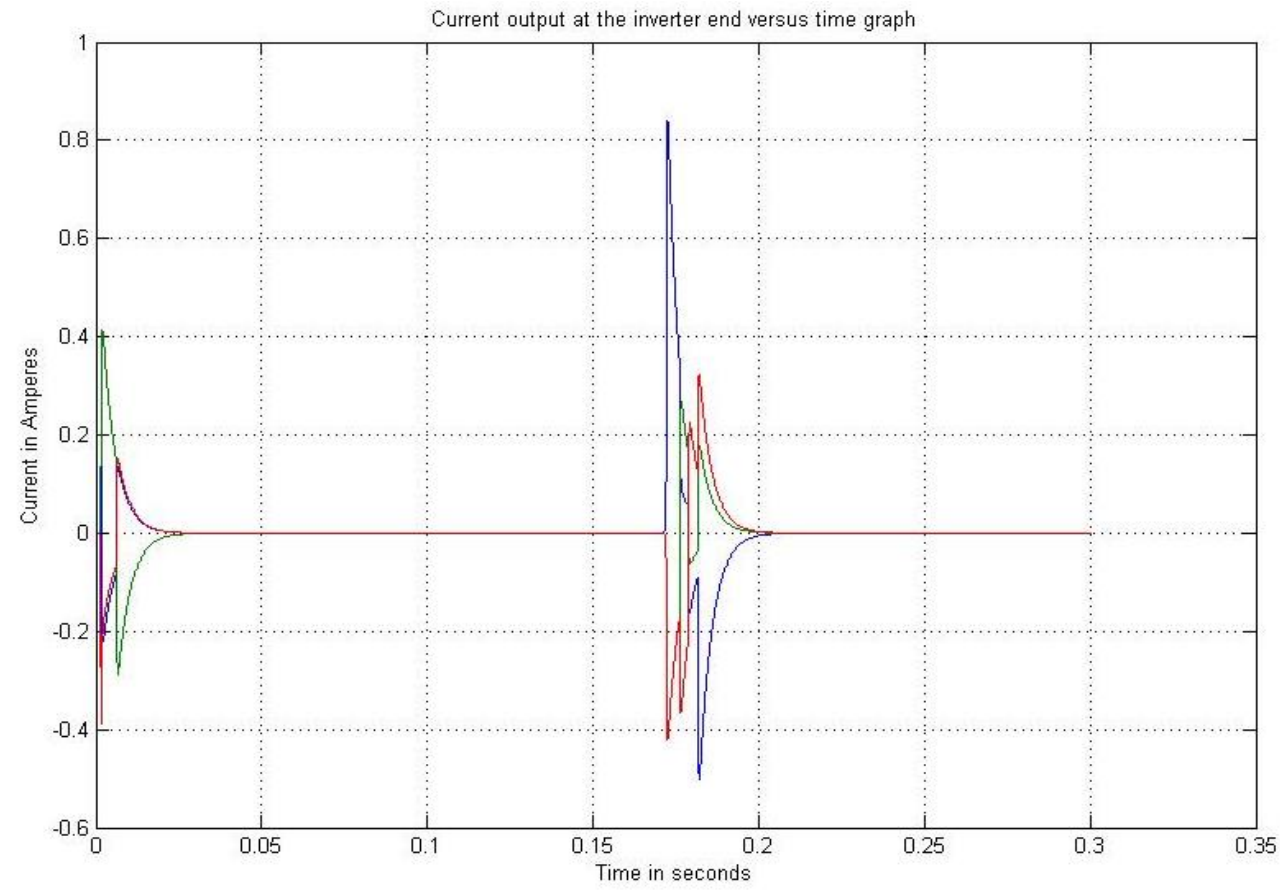

Figure 12: Current Output at the Inverter End.

The Current output at the inverter end is found to be $=0.84 \mathrm{~A}$. 
10. Voltage at the load end:- Voltage $=128.95$ Volts

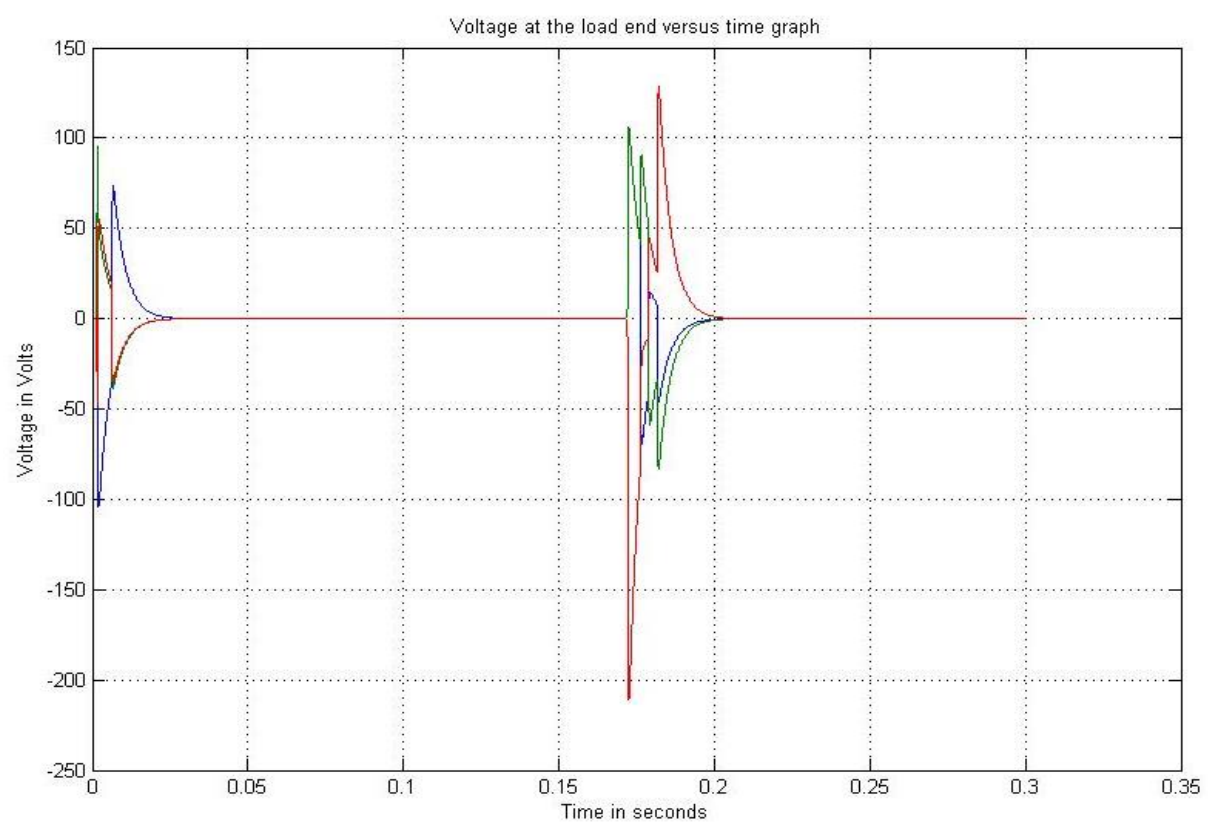

Figure 13: Voltage at the Load End.

The Voltage at the load end is found to be $=128.95$ Volts.

11. Current at the load end:- Current $=20 \mathrm{~A}$

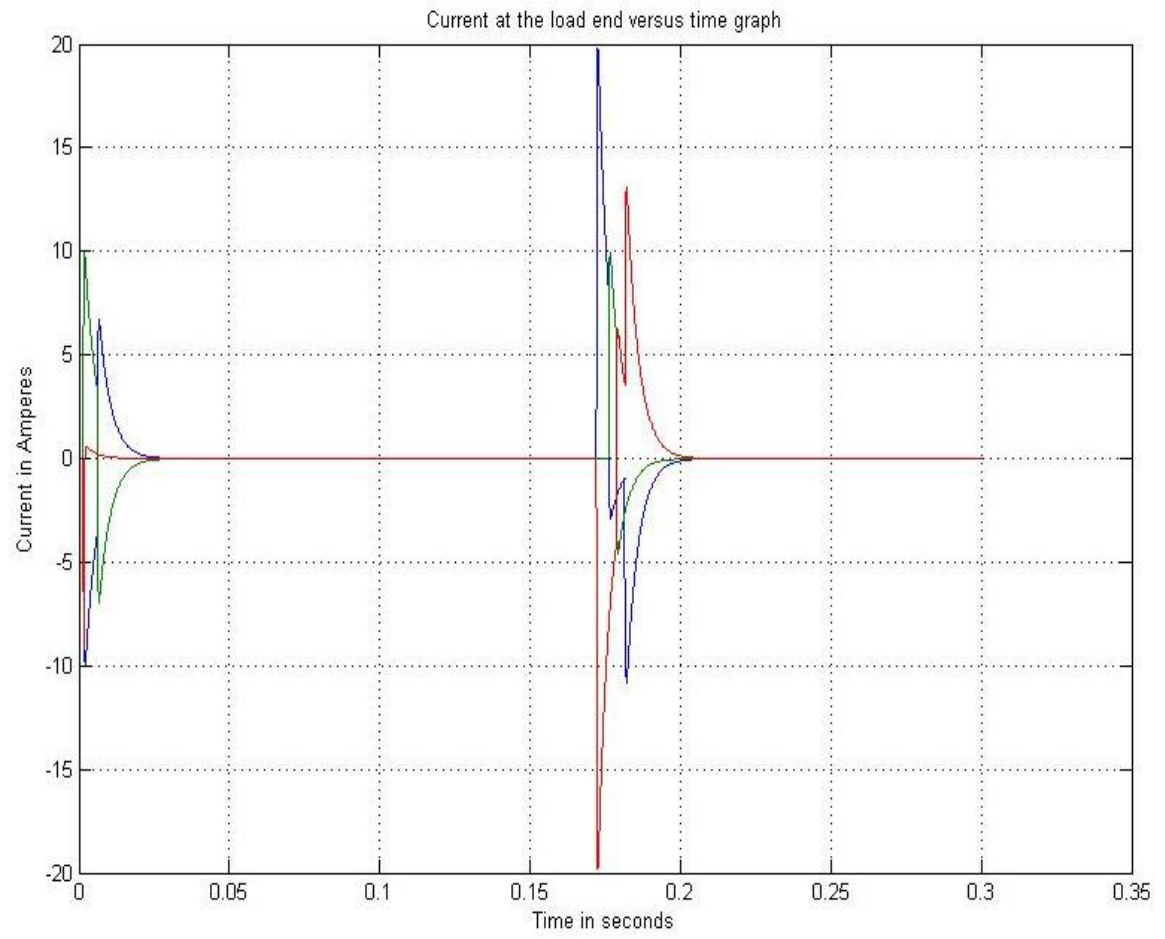

Figure 14: Current at the Load End.

The Current at the load end is found to be $=20 \mathrm{~A}$. 
12. Power at the Load end:- Power is maximum at $=4186$ Watts at 0.1725

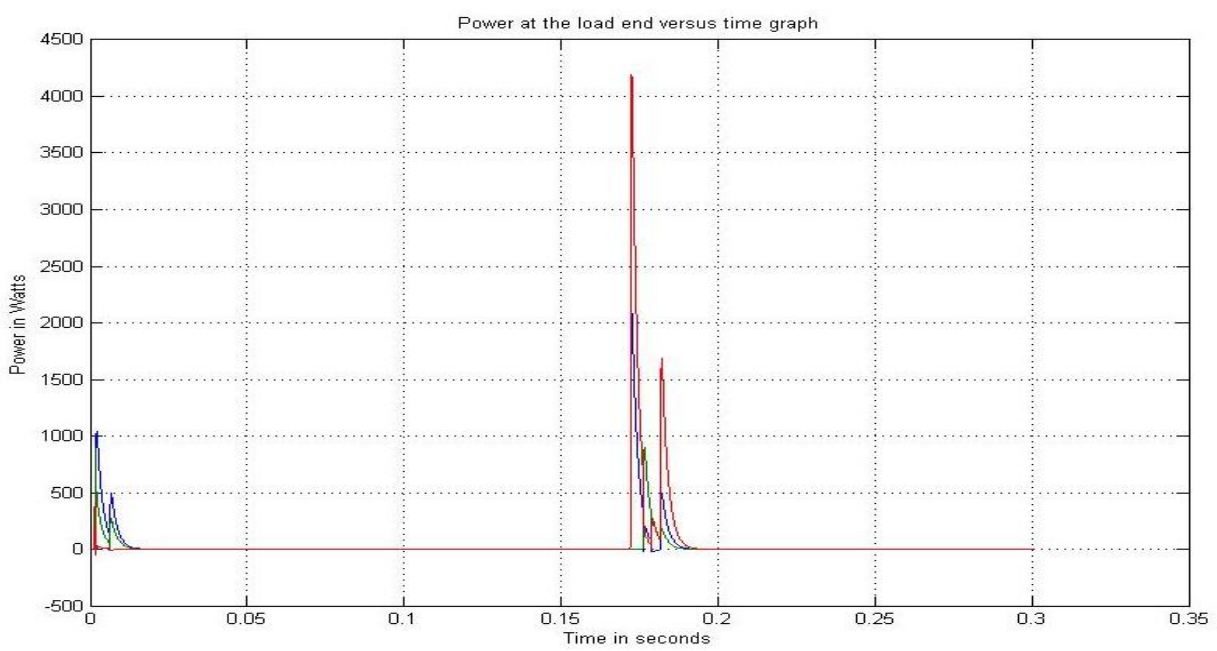

Figure 15: Power at the Load End.

Here, power is found to be maximum at $=4186$ Watts at $0.1725 \mathrm{sec}$.

\section{CONCLUSIONS}

The MATLAB model consisting of Boost converter with Hybrid Energy Storage Systems (HESS) by using PMSG in RAPS systems is simulated and the observations are recorded and observed. The model is tested at $12 \mathrm{mt} . / \mathrm{sec}$ wind speed. The model is made to run in MATLAB and the observations are recorded and observed. Here, we observe that the power at the load end is found to be maximum at 4186 Watts at $0.1725 \mathrm{sec}$. So, the maximum power of the Simulink model is found to be 4186 Watts and the maximum power point of the Simulink model is found to be $0.1725 \mathrm{sec}$.

\section{REFERENCES}

1. Y.Tan, K.M.Muttaqi, P.Ciufo, L.Meegahapola, X.Guo, B.Chen and H.Chen, IEEE Transactions on Power Systems- 2019 on "Enhanced frequency regulation using multi-level energy storage in remote area power supply systems".

2. Patel, G., DILIP B. Patel, and KINJAL M. Paghdal. "Analysis of P\&O MPPT algorithm for PV system." International Journal of Electrical and Electronics Engineering (IJEEE) 5.6 (2016): 1-10.

3. Jiawei Chen, KunchengCai, Ting Lin, “Adaptive Maximum Power Point Tracking Control Strategy for Variable speed wind energy conversion systems with constant tracking speed”, 22nd International Conference on Electrical Machines and Systems (ICEMS)- 2019

4. J. Fang, Y. Tang, H. Li, and X. Li, "A battery/ultra-capacitor hybrid energy storage system for implementing the power management of virtual synchronous generators," IEEE Trans. Power Electron., vol. 33, no. 4, pp. 2820-2824, 2018.

5. I Al-Samarrai, Khalil, Saleh A Sadeg, and Abdullah Sassi. "Policies of Conventional and Non-Conventional Energy for Sustainability in Libya." International Journal of General Engineering and Technology (IJGET) 6.6 (2017): 1-12.

6. J. Cao, W. Du, H. Wang, and M. McCulloch, "Optimal sizing and control strategies for hybrid storage system as limited by grid frequency deviations," IEEE Trans. Power Syst., vol. PP, no. 99, pp. 1-1, 2018.

7. A. Ibrahim, E. Solomin, A. Miroshnichenko, "Control Strategy for Maximum Power Point Trackingof Doubly Fed Induction Motor for Wind Turbine”, 2018 International Ural Conference on Green Energy (UralCon). 
8. Y. Tan, K. M. Muttaqi, P. Ciufo, and L. Meegahapola, "Enhanced frequency response strategy for a PMSG-based wind energy conversion system using ultra-capacitor in remote area power supply systems, " IEEE Trans. Ind. Appl., vol. 53, no. 1, pp. 549$558,2017$.

9. Al-Juboori, Sameer, H. Mutlag Ali, and Rana H. Abduljabbar. "Evaluation of Stand Alone Remote Area Hybrid Power system." International Journal of Electrical and Electronics Engineering (IJEEE) 3.1 (2014): 61-68.

10. Y. Tan, L. Meegahapola, and K. M. Muttaqi, "A sub-optimal power point-tracking-based primary frequency response strategy for DFIGs in hybrid remote area power supply systems, " IEEE Trans. Energy Convers., vol. 31, no. 1, pp. 93-105, 2016.

11. Y. Tan and K. M. Muttaqi, "Multilevel energy storage based frequency regulation in remote area power supply systems," in Proc. 2016 IEEE International Conference on Power System Technology (POWERCON), 2016, pp. 1-6.

12. Kansara, BINDU U., and B. R. Parekh. "Penetration of renewable energy resources based dispatch strategies for isolated hybrid systems." International Journal of Electrical and Electronics Engineering Research (IJEEER) 3 (2013): 121-130.

13. MojtabaAyaz, HosseinAbootorabiZarchi, Mohammad Eydi, “A Fast Maximum Power Point Tracking StrategyBased On Variable Structure Control for Wind Energy Application”, The 4th Iranian Conference on Renewable Energy and Distributed Generation, March 2-3, 2016, Iran, Mashhad.

14. Y. Liu, W. Du, L. Xiao, H. Wang, S. Bu, and J. Cao, "Sizing a hybrid energy storage system for maintaining power balance of an isolated system with high penetration of wind generation, " IEEE Trans. Power Syst., vol. 31, no. 4, pp. 3267-3275, 2016.

15. X. Luo, J. Wang, M. Dooner, and J. Clarke, "Overview of current development in electrical energy storage technologies and the application potential in power system operation," Appl. Energy, vol. 137, pp. 511-536, 2015.

16. Lei Tang, Wei Xu, Chao Xu Mu, "Maximum Power Point Tracking Strategy forPhotovoltaic System Based on Probability", Proceedings of 2015 IEEE International Conference on Applied Superconductivity and Electromagnetic Devices Shanghai, China, November 20-23, 2015.

17. Y. Tan, L. Meegahapola, and K. M. Muttaqi, "A review of technical challenges in planning and operation of remote area power supply systems," Renew. Sustain. Energy Rev., vol. 38, no. 0, pp. 876-889, 2014.

18. M.A. Abdullah, A.H.M. Yatim, C.W. Tan, “An online Optimum-Relation-Based MaximumPower Point Tracking Algorithm for Wind Energy Conversion System”, Australasian Universities Power Engineering Conference, AUPEC 2014, Curtin University, Perth, Australia, 28 September - 1 October 2014.

19. D. Zhou, F. Blaabjerg, M. Lau, and M. Tonnes, "Thermal behavior optimization in multi-MW wind power converter by reactive power circulation," IEEE Trans. Ind. Appl., vol. 50, no. 1, pp. 433-440, 2014.

20. L.-R. Chang-Chien, C.-C. Sun, and Y.-J. Yeh, "Modeling of wind farm participation in AGC," IEEE Trans. Power Syst., vol. 29, no. 3, pp. 1204-1211, 2014.

21. Gwo-Bin Wu, Chin-Sien Moo, "Maximum Power Point Tracking Controlfor Photovoltaic System with Ripple Current", Workshop on Control and Modeling for Power Electronics (COMPEL)-2014 IEEE.

22. K. V. Vidyanandan and N. Senroy, "Primary frequency regulation by de-loaded wind turbines using variable droop," IEEE Trans. Power Syst., vol. 28, no. 2, pp. 837-846, 2013.

23. E. M. Krieger, J. Cannarella, and C. B. Arnold, "A comparison of lead acid and lithium-based battery behavior and capacity fade in off-grid renewable charging applications," Energy, vol. 60, pp. 492-500, 2013.

24. AKINLOLU, AJANI R., et al. "NUTRIENT COMPOSITIONS AND ZINC-BIOAVALABILITY ESTIMATION (IN-VITRO) OF THE EDIBLE TROPICAL CEREALS." International Journal of Applied and Natural Sciences 3.5 (2014): 71-78. 
25. G. Delille, B. Francois, and G. Malarange, "Dynamic frequency control support by energy storage to reduce the impact of wind and solar generation on isolated power system's inertia," IEEE Trans. Sustain. Energy, vol. 3, no. 4, pp. 931-939, 2012.

26. I. D. Margaris, S. A. Papathanassiou, N. D. Hatziargyriou, A. D. Hansen, and P. Sorensen, "Frequency control in autonomous power systems with high wind power penetration," IEEE Trans. Sustain. Energy, vol. 3, no. 2, pp. 189-199, 2012.

27. D. K. Sharma, G. Purohit, “Advanced Perturbation and Observation (P\&O) basedMaximum Power Point Tracking (MPPT) of a Solar Photo-Voltaic System”, IEEE paper-2012.

28. T. Goya, E. Omine, Y. Kinjyo, T. Senjyu, A. Yona, N. Urasaki, and T. Funabashi, "Frequency control in isolated island by using parallel operated battery systems applying h-infinity control theory based on droop characteristics, "IET Renew. Power Gen., vol. 5, no. 2, pp. 160-166, 2011.

29. L. Wei, G. Joos, and J. Belanger, "Real-time simulation of a wind turbine generator coupled with a battery super-capacitor energy storage system," IEEE Trans. Ind. Electron., vol. 57, no. 4, pp. 1137-1145, 2010.

30. C. Abbey, K. Strunz, and G. Joos, "A knowledge-based approach for control of two-level energy storage for wind energy systems," IEEE Trans. Energy Convers., vol. 24, no. 2, pp. 539-547, 2009.

31. OH-P1-Team, "Operation hand book policy 1: Load-frequency control and performance," Union for the Co-ordination of Transmission of Electricity 2009.

32. A. R. Panel, "Application of frequency operating standards during periods of supply scarcity, final determination," 15 April, 2009.

33. J. F. Conroy and R. Watson, "Frequency response capability of full converter wind turbine generators in comparison to conventional generation, "IEEE Trans. Power Syst., vol. 23, no. 2, pp. 649-656, 2008.

34. G. Ramtharan, J. B. Ekanayake, and N. Jenkins, "Frequency support from doubly fed induction generator wind turbines, "IET Renew. Power Gen., vol. 1, no. 1, pp. 3-9, 2007.

\section{AUTHOR PROFILE}

\section{Rohit Sinha}

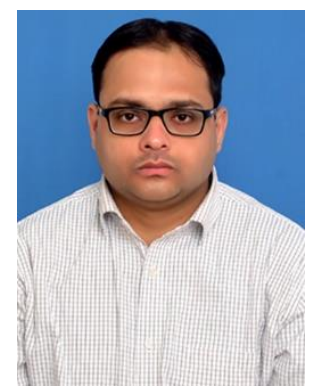

Rohit Sinha, received his B.Tech degree in Electrical \& Electronics Engineering from Gandhi Engineering College (GEC), Bhubaneshwar, Odisha, India, which is affiliated to BijuPatnaik University of Technology (BPUT), Rourkela, Odisha, India in the year 2012. He has one year industrial experience in private sector in India. He is currently working towards his M.Tech degree in Electrical Engineering (Power System \& Control Specialization) at School of Engineering, Department of Electrical Engineering, of BabuBanarasi Das University, Lucknow, Uttar Pradesh, India. His research interests are in Power System, Renewable energy and Power Transmission and Distribution. 


\section{Virendra Kumar Maurya}

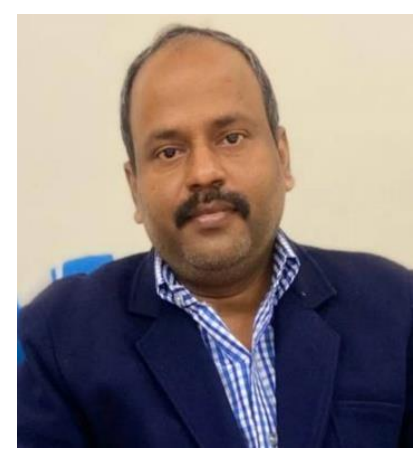

Virendra Kumar Maurya, is currently Associate Professor and Head of the Department of Electrical Engineering, School of Engineering, Department of Electrical Engineering, of Babu Banarasi Das University, Lucknow, Uttar Pradesh, India. 
